\title{
ASPEK YURIDIS DAN IMPLIKASI HAK GUNA RUANG ATAS DAN BAWAH TANAH
}

\section{JURIDICIAL ASPECT AND IT'S IMPLICATION OF AIR SPACE AND UNDERGROUND LAND USE RIGHTS}

\author{
Trie Sakti \\ Pusat Penelitian dan Pengembangan Kementerian ATR/BPN, Jalan H. Agus Salim Nomor 58, Jakarta, \\ triesakti@yahoo.com
}

\begin{abstract}
ABSTRAK
Perkembangan pembangunan di perkotaan menunjukkan bahwa pemanfaatan ruang di perkotaan tidak terbatas pada bidang tanah saja tetapi termasuk juga ruang atas dan bawah tanah. Permasalahan timbul ketika terjadi pembangunan mall di bawah tanah, MRT, underpass, flyover, terkait status hak yang akan diberikan mengingat hak atas tanah diartikan hanya sebatas yang ada di permukaan bumi, kemudian seberapa jauh batas ketinggian yang boleh dipergunakan pihak lain dan seberapa jauh batas kedalaman yang dapat dipergunakan pihak lain. Peraturan perundangan yang ada belum secara spesifik mengatur mengenai penggunaan pemanfaatan Hak Guna Ruang Atas dan Bawah Tanah (HGRBT) sehingga timbul berbagai penafsiran terhadap ketentuan yang ada. Mengingat perkembangan teknologi yang semakin maju dan terbatasnya tanah yang tersedia maka perlu segera disusun peraturan perundang-undangan mengenai Hak Guna Ruang Atas dan Bawah Tanah dan harmonisasinya dengan peraturan lain di tingkat pusat dan daerah terkait penataan ruang, lingkungan hidup, pertambangan, Rencana Tata Ruang Wilayah (RTRW) dan Rencana Detail Tata Ruang (RDTR). Kajian ini menelaah dan menganalisis data sekunder sebagai sumber utama. Pendekatan yang dipergunakan dalam pendekatan ini adalah pendekatan perundang-undangan, pendekatan konseptual, serta pendekatan historis. Pendekatan terhadap peraturan perundangan dilakukan dengan cara menganalisis terhadap ketentuan hukum yang terkait.
\end{abstract}

Kata kunci : Hak Guna Ruang, Hak Guna Ruang Atas Tanah, hukum, regulasi, rencana tata ruang wilayah, Rencana Detail Tata Ruang, Ruang atas Tanah, Ruang Bawah tanah.

\section{ABSTRACT}

The current development of urban infrastructure depicts that space utilization in an urban area is not only limited to ground land but also to everything lies on top and beneath of it including buildings and the underground level. The problem may arise when there is a construction for an underground mall, MRT, underpass, or flyover, regarding the given rights of a certain land. This is considering that this right is aimed only at the space on the ground area, while for the height limit to the top and the depth level below the ground for utilization has not been regulated yet. The existing regulation has not specifically governed the use of space rights for over and below the ground (HGRBT) which then leads to the multi-interpretation of the current provision. With regards to the technology enhancement nowadays and limited land available; there is a critical need to start constructing a new regulation that rules the space usage rights of above and below the ground as well as harmonizing the other existing related regulations both at central and regional level. These related regulations may include spatial planning in general, mining, spatial planning master plan (RTRW), and spatial planning detail plan (RDTR). This paper obtains and uses secondary data as its primary source for analysis and review. In addition, this paper uses both legal, conceptual, and historical approach to deepen the study and investigation on this subject. 
Legislation approach is conducted by analyzing any specific and related laws and regulations.

Keywords: space usage right, space right, legal, regulation, spatial planning, over ground space, below ground space

\section{PENDAHULUAN}

\section{Latar Belakang}

Pertumbuhan ekonomi yang terus meningkat memberi pengaruh pada intensitas pembangunan, dan Indonesia sebagai negara berkembang dengan pertumbuhan ekonomi yang cukup baik bahkan menjadi salah satu pasar potensial dunia (emerging market). Dengan meningkatnya kemajuan ekonomi di Jakarta, maka muncul pula berbagai masalah ibu kota, salah satunya adalah masalah kemacetan di jalan raya, pemandangan yang bagi sebagian warga Jakarta tentu tidak asing lagi. Maka tuntutan pembangunan sarana dan prasarana untuk mendukung aktivitas ekonomi sangat diharapkan bukan hanya di ibukota negara tetapi juga di berbagai ibukota provinsi di sebagian wilayah Indonesia.

Sementara itu, trend pembangunan di Indonesia semakin meningkat terutama pembangunan infrastruktur yang menjadi salah satu primadona pembangunan saat ini. Pembangunan infrastruktur seperti jalan layang, monorail, MRT, basement, dan sebagainya sudah sangat diperlukan. Namun demikian pelaksanaan pembangunan terkendala dengan terbatasnya tanah yang tersedia sehingga tanah menjadi komoditi yang mahal, disisi lain kebijakan yang ada belum menampung perkembangan tuntutan pembangunan baik yang sudah berjalan maupun yang baru akan dilaksanakan.
Beberapa permasalahan muncul ketika di jalan protokol Jakarta terjadi pembangunan jembatan penyebrangan umum yang menghubungkan dua gedung dan dibangun oleh swasta di atas tanah publik (jalan raya). Dengan demikian dapat dikatakan bahwa pembangunan jembatan ini bukan hanya untuk kepentingan warga tetapi juga untuk kepentingan usaha, demikian juga pembangunan area bawah tanah terminal blok $\mathrm{M}$, dimana telah disewakan untuk kepentingan usaha/dagang, dan yang gencar dibicarakan mengenai rencana pembangunan lintasan MRT berikut stasiun bawah tanahnya juga akan berada di bawah permukaan tanah milik pihak lain dan kemungkinan besar juga akan digunakan untuk kepentingan usaha.

Ketentuan dalam Pasal 33 Undang-undang Dasar 1945 mewajibkan Negara untuk mengatur pemilikan tanah dan memimpin penggunaannya, hingga semua tanah di seluruh wilayah kedaulatan bangsa dipergunakan untuk sebesar-besar kemakmuran rakyat, baik secara perseorangan maupun secara gotong royong. Hak atas tanah bersumber dari hak menguasai dari negara atas tanah yang dapat diberikan kepada perseorangan, baik Warga Negara Indonesia maupun Warga Negara Asing, dan sekelompok orang secara bersama-sama, serta badan hukum, baik badan hukum privat maupun badan hukum publik. Hak atas tanah hanya diperuntukkan untuk permukaan bumi saja. Jika pemanfaatan tanah berbeda antara pemanfaatan tanah yang 
ada di permukaan bumi dengan pemanfaatan yang ada di ruang atas tanah maupun ruang bawah tanah, maka kewenangan pemegang hak atas tanah yang ada dipermukaan bumi tidak dapat menjangkau penguasaannya atas pemanfaatan tanah di ruang atas tanah maupun ruang bawah tanah.

Dalam pemanfaatan hak atas ruang maka perlu diperhatikan penataan ruang yang mempertimbangkan keserasian, keselarasan antara pemanfaatan tanah untuk pembangunan dengan kesejahteraan rakyat dengan tetap memperhatikan pelestarian fungsi lingkungan hidup, tentunyajuga dengan mempertimbangkan penatagunaan tanah berasaskan keterpaduan, berdayaguna dan berhasil guna, serasi, selaras, seimbang, berkelanjutan, keterbukaan, persamaan, keadilan dan perlindungan hukum. pemanfaatan ruang atas tanah dan ruang bawah tanah juga perlu mempertimbangkan aspek ekonomi berkaitan dengan keterbatasan tanah dan penghematan biaya, serta memperhatikan aspek keselamatan, keamanan, estetika maupun penggunaan ruang untuk kepentingan publik.

Pada tahun 2006, Puslitbang BPN-RI telah melaksanakan Penelitian Penguasaan Pemilikan penggunaan dan Pemanfaatan Ruang Atas dan Ruang Bawah Tanah Untuk Kepentingan Pembangunan. Dalam penelitian tersebut diketahui bahwa pemahaman dan pengertian tentang keberadaan pemanfaatan ruang atas tanah dan ruang bawah tanah di lokasi penelitian khususnya maupun Indonesia pada umumnya masih terasa asing bagi sebagian besar aparat pemerintah di daerah maupun masyarakat lainnya. Oleh karenanya hal ini akan menjadi tantangan pada masa depan sejalan dengan kemajuan teknologi pembangunan pemanfaatan ruang, maka seyogianya pemerintah Indonesia dalam hal ini BPN-RI perlu banyak belajar dan menggali pengaturan dan pendaftaran jenis-jenis hak ini ke negara yang sudah maju dalam pengelolaan hak guna ruang atas tanah dan ruang bawah tanah tersebut.

Hasil penelitian tersebut merekomendasikan bahwa 1) konsep hak guna ruang atas tanah dan hak guna ruang bawah tanah dapat dikembangkan bila ada perubahan konsep dasar hukum tanah nasional dari azas pemisahan horizontal hak atas tanah menjadi azas pemisahan vertikal hak guna ruang. Dengan konsep pemisahan horizontal menggariskan bahwa pada umumnya pemilik bangunan sekaligus juga pemilik tanahnya, sedangkan konsep pemisahan vertikal hak guna ruang memungkinkan bahwa pemilik bangunan tidak selalu pemilik tanahnya, melainkan dapat pula milik pihak lain, 2) seyogianya perlu pula dilakukan peninjauan kembali mengenai definisi hak atas tanah (hak di permukaan bumi) yang selama ini dikenal dalam Pasal 4 dan 16 UUPA dengan memberikan beberapa kriteria dan pembatasan yang jelas, serta menyusun definisi mengenai hak guna ruang atas tanah (hak di atas permukaan bumi) dan hak guna ruang bawah tanah (hak di bawah permukaan bumi) berdasarkan beberapa kriteria dan pembatasan yang diperlukan untuk keamanan, keselamatan, kenyamanan, dan sebagainya, 3) untuk pemanfaatan ruang yang dikelola oleh pemerintah, pemerintah daerah atau 
badan hukum bentukan pemerintah sebaiknya dilekatkan Hak Pengelolaan (HPL), yaitu HPL Guna Ruang Atas Tanah (HPLGRAT) untuk pembangunan jalan raya di atas tanah (jalan layang), dan HPL Guna Ruang Bawah Tanah (HPLGRBT) untuk pembangunan jalan raya di bawah tanah (terowongan, subway), dan sebagainya, sedangkan untuk pemanfaatan ruang kepentingan umum (areal bisnis, cafe, perdagangan, dsb) seyogianya diberikan Hak Guna Bangunan (HGB) dan/atau Hak Pakai (HP) dengan melakukan perpaduan/modifikasi dengan Hak Sarusun, yaitu HGB Ruang Atas Tanah (HGBRAT) dan HGB Ruang Bawah Tanah (HGBRBT) dan/atau HP Ruang Atas Tanah (HPRAT) dan HP Ruang Bawah Tanah (HPRBT).

Dalam RUU Pertanahan, diusulkan bahwa ruang yang berada di atas dan/atau bawah tanah yang dikuasai oleh pemegang hak atas tanah yang berbeda dengan pemegang hak atas tanah, dapat diberikan Hak Guna Ruang dengan persetujuan pemegang hak atas tanah.

Mengingat perkembangan kota terutama kotakota besar seperti Jakarta mulai menghadapi masalah keterbatasan tanah untuk kegiatan sosial-ekonomi yang berkembang pesat maka pemanfaatan ruang secara vertikal di atas bumi merupakan alternatif pertama yang sering dilakukan untuk mengatasi keterbatasan tanah tersebut. Meskipun demikian dengan makin tingginya nilai tanah, dan kebutuhan tanah, banyak kota-kota besar di dunia memanfaatkan ruang atas dan bawah tanah sebagai salah satu alternatif solusi.

\section{Permasalahan}

Berdasarkan latar belakang tersebut maka yang menjadi permasalahan adalah:

1. Apakah ketentuan perundangan yang ada sudah dapat mengakomodir penggunaan dan pemanfaatan ruang atas tanah dan ruang bawah tanah?

2. Apakah Lembaga baru Hak Ruang Bawah Tanah sangat diperlukan?

\section{Tujuan}

1. Untuk mengetahui ketentuan perundangan yang ada sudah dapat mengakomodir penggunaan dan pemanfaatan ruang atas tanah dan ruang bawah tanah.

2. Untuk mengetahui pentingnya pembentukan lembaga baru Hak Ruang Bawah Tanah.

\section{Metode}

Kajian dengan judul Aspek Yuridis Dan Implikasi Hak Guna Ruang Dan Bawah Tanah Adalah merupakan kajian Yuridis Normatif, yaitu dengan menelaah dan menganalisis data sekunder sebagai sumber utama. Pendekatan yang dipergunakan dalam pendekatan ini adalah pendekatan perundang-undangan, pendekatan konseptual, serta pendekatan historis. Pendekatan terhadap peraturan perundangan dilakukan dengan cara menganalisis terhadap ketentuan hukum, khususnya UUPA, UU nomor 26 tahun 2007 tentang Penataan Ruang, UU Nomor 1 tahun 2011 tentang Rumah Susun, Undang-Undang Nomor 28 Tahun 2002 juncto Peraturan Pemerintah Nomor 36 Tahun 2005 tentang Bangunan Gedung, serta peraturan 
lain yang terkait untuk menentukan Pengaturan Penggunaan dan Pemanfaatan Ruang bawah tanah.

\section{Model Penggunaan dan Pemanfaatan Ruang Atas dan Bawah Tanah}

Pengertian HGRAT, antara lain merupakan: 1) Hak untuk menggunakan permukaan bumi (tanah) seperti hak milik, hak pakai, dan hak guna usaha; 2)Hak untuk menggunakan ruang di atas permukaan bumi dan di dalam tubuh bumi; 3) Hak mempunyai bangunan yang terdapat dalam ruang di atas permukaan bumi dan dalam tubuh bumi.

Ruang lingkup Hak Guna Ruang Atas Tanah (HGAT) meliputi: ${ }^{1}$

1. Hak Guna Ruang Atas Tanah meliputi hak atas permukaan bumi tempat pondasi bangunan dan hak untuk menguasai ruang udara seluas bangunan tersebut serta hak kepemilikan bangunan;

2. HGAT tidak terlepas dari hak untuk memiliki atau mepergunakan tanah, perlu dilandasi dengan sesuatu hak atas tanah, misalnya; hak untuk memiliki tanah atau hak guna bangunan, dan hak pakai untuk menggunakan tanah atau memanfaatkan hasil tanah;

3. Diperlukan hak untuk menggunakan ruang udara di atas permukaan bumi yang dihakinya, ataupun di atas hak orang lain;

4. Diperlukan hak untuk memiliki bangunan guna kepastian hukum, dari bangunan itu sendiri yang mungkin nilai ekonominya

1 https://eleveners.wordpress.com/2010/01/19/dir-pendaftaranhak-tanah-dan-guna-ruang/ lebih tinggi dari tanah tempat pondasi bangunan.

Hak Guna Ruang Bawah Tanah (HGBT) meliputi:2

1. Hak Guna Ruang Bawah Tanah meliputi hak atas permukaan bumi yang merupakan pintu masuk/keluar tubuh bumi dan hak membangun dan memakai ruang dalam tubuh bumi, serta hak milik atas bangunan yang berbentuk ruang dalam tubuh bumi;

2. HGBT tidak terlepas dari hak atas tanah. Untuk memiliki/menggunakan tanah sebagai pintu masuk/keluar tubuh bumi harus dilandasi dengan suatu hak atas tanah;

3. Sebagai landasan hak untuk menggunakan/ memiliki ruangan di dalam tubuh bumi, di bawah tanah yang menjadi hak orang lain;

4. Untuk kepastian hukum dalam kepemilikan bangunan dalam ruang di dalam tubuh bumi.

Ada beberapa model penggunaan dan pemanfaatan ruang atas dan bawah tanah tidak hanya di Jakarta tetapi juga di daerah seperti:

1. Lapangan Karebosi - Makassar

Dalam melakukan revitalisasi terhadap Lapangan Karebosi, Pemerintah Kota Makassar melakukan kerjasama dengan PT Tosan Permai Lestari yang disebut dengan Kerjasama Bangun Guna Serah. Dalam Perjanjian ini PT Tosan bertanggungjawab membangun Revitalisasi Lapangan Karebosi tanpa ada biaya dari Pemerintah Kota Makassar. Sebagai Imbalan, PT Tosan Permai Lestari diberikan hak 2 Ibid 
untuk mengelola selama 30 (tiga puluh) tahun, kemudian akan diserahkan kepada Pemerintah Kota Makassar. Bagian lapangan seluas 4,3 ha yang revitalisasi, dimana 2,58 ha. (60\%) berfungsi sebagai fasilitas sosial yaitu sebagai areal parkir (parking lot), 1,72 ha $(40 \%)$, berfungsi sebagai areal komersial yang berada di bawah permukaan lapangan (sebagai fungsi penunjang). Jenis-jenis kegiatan yang ada di atas permukaan lapangan karebosi pasca revitalisasi adalah areal parkir, panggung upacara, lapangan softball, area senam, skateboard, helipad, lapangan futsal, lapangan sepakbola, lapangan bola basket, lapangan tennis, jalur pedestrian, dan pelataran beringin.

Prokontrastatus hukum Lapangan Karebosi ini kemudian diajukan ke Pengadilan. Kalangan masyarakat yang tidak mendukung revitalisasi Lapangan Karebosi kemudian menggugat Pemerintah Kota Makassar melalui gugatan warga negara (citizen lawsuit). ${ }^{3}$ Mereka menilai bahwa tergugat yang antara lain Pemerintah Kota Makassar, Dinas Tata Kota dan Bangunan Kota Makassar dan Propinsi Sulawesi Selatan, Bapedalda Kota Makassar dan Propinsi Sulawesi Selatan, DPRD Kota Makassar, serta PT Tosan Permai Lestari telah mengalihfungsikan Lapangan Karebosi melalui revitalisasi tersebut serta mengkomersilkan barang milik atau aset Warga Makassar. Penggugat menilai bahwa masyarakat tidak lagi dapat menikmati Lapangan Karebosi secara gratis. Begitu

3 Ismail Alrip, Farida Patittingi, Faisal Abdullah, Pengaturan Pemanfaatan Ruang Bawah TanahFakultas Hukum, Pascasarjana, Universitas Hasanuddin juga dengan pedagang yang dulunya berjualan di Lapangan Karebosi harus rela kehilangan lokasi berdagangnya. ${ }^{4}$

Pengadilan Negeri Makassar kemudian dalam putusannya memenangkan Pemerintah KotaMakassar sehingga secara tidak langsung, maka Pemerintah Kota Makassar dinilai berwenang melakukan pengelolaan terhadap Lapangan Karebosi. Berkaitan dengan Pemanfaatan Ruang Bawah Tanah, Pemerintah Kota Makassar tidak menerbitkan Peraturan Daerah atau Peraturan Walikota.

2. Underpass Dewa Ruci Bali

Pemanfaatan Ruang Bawah Tanah pada Underpass Dewa Ruci hanya dimanfaatkan sebagai jalan umum, tidak ada fasilitas lain dalam underpass tersebut. Pembangunan Underpass Dewa Ruci Bali hanya didasarkan pada AMDAL dan UPLUKL. Pemerintah atau Pemerintah Kota Denpasar tidak menerbitkan Peraturan daerah yang memberikan izin mengenai pemanfaatan ruang bawah tanah dalam pembangunannya.

Pembangunan jalan underpass merupakan upaya pemerintah dalam mengurangi kemacetan lalu lintas di Kota Denpasar dan Kabupaten Badung, khususnya di wilayah Kuta yang merupakan daerah tujuan wisata favorit. Pemilik Tanah underpass Dewa Ruci sebelum dibangun sebagian adalah tanah milik masyarakat yang kemudian dilakukan pengadaan tanah untuk kepentingan umum.

3. Pusat Perbelanjaan di bawah terminal Bis

4 www.bkm.go.id 
Blok M Jakarta ( Blok M MALL)

Blok M mall yang berada di bawah tanah, tepat di bawah terminal Blok M. Dibangun pada tahun 1993, terintegrasi langsung dengan terminal bus dan Blok M Square.

Blok M Mall adalah satu-satunya Mall yang berada di bawah Terminal Bus dan dipadukan dengan Taman Kota.

4. Jembatan penyeberangan yang berfungsi sebagai toko seperti di Pondok Indah Mall, Pasar Tanah Abang, Glodok, ITC Mangga Dua;

Di beberapa Pusat Pertokoan di jakarta cukup banyak yang menggunakan jembatan penyeberangan antar pusat pertokoan sebagai toko, hal ini tentunya perlu diberikan dasar hukum terhadap penggunaan dan pemanfaatan jembatan penyeberangan sebagai toko.

5. Flyover Antasari-Blok M dan Kampung Melayu-Tanah Abang (Casablanca).

Meski banyak pihak yang memprotes bahwa kebijakan pembangunan jalan layang (flyover) hanya akan menambah kemacetan, pemerintah tetap akan membangun flyover di sejumlah titik untuk mengurai kemacetan. Jalan layang (flyover) adalah jalan yang dibangun tidak sebidang melayang menghindari daerah/kawasan yang selalu menghadapi permasalahan kemacetan lalu lintas, melewati persilangan kereta api untuk meningkatkan keselamatan lalu lintas dan efisiensi. Jalan layang merupakan perlengkapan jalan bebas hambatan untuk mengatasi hambatan karena konflik persimpangan, melalui kawasan kumuh yang sulit ataupun melalui kawasan rawa-rawa. ${ }^{5}$

Di Jakarta, flyover Antasari memiliki panjang 4,8 kilometer dengan lebar 17,75 meter untuk dua jalur. Sementara flyover Kampung Melayu-Tanah Abang dibangun sepanjang 1,8 kilometer, yaitu di atas Jalan Dr Satrio hingga Jalan Mas Mansyur.

Pemerintah Provinsi DKI Jakarta saat ini mulai membangun megaproyek Flyover Semanggi, jalan berbentuk lengkung lingkaran itu akan menghubungkan kendaraan dari arah Grogol menuju Senayan dan Sudirman menuju Cawang. Flyover diharapkan dapat mengurangi 30 persen kemacetan. Dengan adanya flyover tersebut, kendaraan dari Jalan Gatot Subroto tak akan bertemu dengan kendaraan dari Jalan Sudirman di kolong jembatan.

6. MRT

Mass Rapid Transit (MRT) artinya adalah angkutan yang dapat mengangkut penumpang dalam jumlah besar secara tepat. MRT yang merupakan suatu sistem transportasi perkotaan ini memiliki kriteria utama yaitu, mass (daya angkut besar), rapid (waktu tempuh cepat dan frekuensi tinggi), dan transit (berhenti di banyak stasiun di titik utama perkotaan). Beberapa bentuk dari MRT antara lain berdasarkan jenis fisik ${ }^{6}$ :

a. Bus Rapid Transit (BRT), Sistem transportasi berbasis jalan yang menkombinasikan elemen stasiun dan kendaraan dengan sistem perencanaan transportasi kota, 
umumnya mencakup jalur bus yang terpisah dan modernisasi teknologi bus. BRT umumnya mencakup:

1) Sistem turun-naik penumpang yang cepat;

2) Sistem tiket efisien;

3) Stasiun dan halte yang nyaman;

4) Teknologi bus yang ramah lingkungan;

5) Integrasi moda transportasi;

6) Pelayanan konsumen yang baik.

b. Light Rapid Transit (LRT)

Sistem transportasi metropolitan dengan menggunakan kereta rel listrik yang ditandai dengan kemampuan mengoperasikan gerbong pendek seperti monorel dan trem di sepanjang jalur eksklusif baik di bawah tanah, udara atau di jalan.

c. Heavy Rapid Transit (HRT), Sistem transportasi metropolitan yang menggunakan kereta berkinerja tinggi, digerakkan secara elektrik, beroperasi di jalur eksklusif, tanpa jalur persilangan, dengan peron stasiun yang besar, serta memiliki kapasitas besar.

Dasar Hukum dari pembangunan MRT adalah Peraturan Gubernur Nomor 167 Tahun 2012 tentang Ruang Bawah Tanah. Peraturan Gubernur ini merupakan tindak lanjut dari Pasal 198 ayat (5) Peraturan Daerah Provinsi DKI Jakarta Nomor 1 Tahun 2012 tentang Rencana Tata Ruang Wilayah 2030. Dalam Pasal 3 disebutkan bahwa Pemanfaatan Ruang Bawah Tanah dilaksanakan sesuai dengan Rencana
Tata Ruang Wilayah, RDTR dan Peraturan Zonasi serta Master Plan Pengembangan Kawasan dan Panduan Rancang Tata Kota pada lokasi kegiatan pemanfaatan ruang bawah tanah. Ruang bawah tanah terdiri atas ruang bawah tanah dangkal dan ruang bawah tanah dalam. Ruang bawah tanah dangkal merupakan ruang di bawah permukaan tanah sampai dengan ke dalaman $10 \mathrm{~m}$ (sepuluh meter). Ruang bawah tanah dalam merupakan ruang di bawah permukaan tanah dari ke dalaman $10 \mathrm{~m}$ sampai dengan batas kemampuan pemanfaatan ruang bawah tanah.

\section{HASIL DAN PEMBAHASAN}

Kepemilikan hak atas tanah termasuk salah satu hak asasi manusia yang dilindungi oleh hukum nasional yang sudah di jelaskan dalam pasal 28 H ayat (4) Undang-Undang Dasar tahun 1945 bahwa: "setiap orang berhak mempunyai hak milik pribadi dan hak milik tersebut tidak boleh diambil alih secara sewenang-wenang oleh siapa pun". Selain itu pasal 33 ayat (3) UndangUndang Dasar tahun 1945 menyatakan juga bahwa bumi, air, dan kekayaan alam yang terdapat di dalamnya dikuasai negara dan dipergunakan sebesar-besarnya bagi kemakmuran rakyat. Hal ini dengan jelas mengandung amanat kostitusional yang sangat mendasar, yaitu bahwa pemanfaatan dan penggunaan tanah harus dapat mendatangkan kesejahteraan sebesar-besarnya bagi seluruh rakyat Indonesia.

Makna dikuasai dari pasal 33 UndangUndang Dasar 1945 kemudian di jelaskan dalam Undang-Undang No. 5 tahun 1960, 
mengenai hak menguasai oleh negara dalam Pasal 2 ayat (2) bahwa kewenangan negara adalah: Mengatur dan menyelenggarakan peruntukan, penggunaan, persediaan tanah atau pemeliharaannya ; a. Menentukan dan mengatur hak - hak yang dapat dipunyai atas (bagian dari) bumi, air, dan ruang angkasa itu. b. Menentukan dan mengatur hubungan - hubungan hukum antara orang-orang dan perbuatan - perbuatan hukum yang mengenai bumi, air, dan ruang angkasa , segala sesuatunya dengan tujuan untuk mencapai sebesar besarnya kemakmuran rakyat dalam masyarakat adil dan makmur.

Dalam pembahasan mengenai pemanfaatan ruang atas dan bawah tanah secara otomatis akan berkaitan dengan hak-hak atas tanah, penataan ruang dan perijinan baik sektoral maupun peraturan daerah.

\section{Undang-Undang Pokok Agraria (UUPA)}

Menurut Pasal 1 UUPA, ruang lingkup bumi adalah permukaan bumi, dan tubuh bumi di bawahnya serta yang berada di bawah air. Permukaan bumi sebagai bagian dari bumi juga disebut tanah. Tanah yang dimaksud bukan dalam pengaturan di segala aspek, tetapi hanya mengatur salah satunya, yaitu tanah dalam pengertian yuridis yang disebut hak-hak penguasaan atas tanah. Pasal 4 UUPA mencantumkan bahwa: (1) Atas dasar hak menguasai dari Negara sebagai yang dimaksud dalam Pasal 2 ditentukan adanya macam-macam hak atas permukaan bumi yang disebut tanah, yang dapat diberikan kepada dan dipunyai oleh orang-orang baik sendiri maupun bersama-sama dengan orang lain serta badan-badan hukum, (2) Hak-hak atas tanah yang dimaksud dalam ayat (1) pasal ini memberi wewenang untuk mempergunakan tanah yang bersangkutan demikian pula tubuh bumi dan air serta ruang yang ada diatasnya, sekedar diperlukan untuk kepentingan yang langsung berhubungan dengan penggunaan tanah itu dalam batas-batas menurut undangundang ini dan peraturan-peraturan hukum lain yang lebih tinggi, (3) Selain hak-hak atas tanah sebagai yang dimaksud dalam ayat (1) pasal ini ditentukan pula hak-hak atas air dan ruang angkasa. ${ }^{7}$

Selanjutnya dalam Pasal 4 ayat (1) mengatur bahwa hak atas tanah adalah hak ataspermukaan bumi (dua dimensi panjang kali lebar) maka satuan hak atas tanah dalam sertipikat hak atas tanah adalah "luas", sedangkan Pasal 4 ayat (2), mengatur "sekedar" yaitu sekedar untuk mendukung penggunaan permukaan bumi pemegang hak atas tanah dapat menggunakan ruang atas tanah atau tubuh bumi di dalamnya. Namun sampai saat ini pengaturan "sekedar" tidak secara eksplisit diatur, tapi pada kenyataannya "sekedar" tersebut sudah diterjemahkan dalam "kebijakan penataan ruang" misalnya ada terdapat zonazona yang dapat membangun bangunan tingkat tinggi, terdapat zona yang hanya dapat membangun rumah satu lantai dan lainnya.

Berkaitan dengan hak-hak atas tanah diatur pada Pasal 16 yaitu: (1). Hak-hak atas tanah

\footnotetext{
7 Sri Maharani, 'Hukum Ruang Bawah Tanah", Presentasi dan Paper yang dipaparkan dalam Focus Group Discussion yang diselenggarakan oleh Badan Pengembangan Infrastruktur Wilayah, Kementerian Pekerjaan Umum dan Perumahan Rakyat, 7-8 Oktober 2015.
} 
sebagai yang dimaksud dalam Pasal 4 ayat (1) ialah:

1. hak milik,

2. hak guna-usaha,

3. hak guna-bangunan,

4. hak pakai,

5. hak sewa,

6. hak membuka tanah,

7. hak memungut hasil hutan,

8. hak-hak lain yang tidak termasuk dalam hak-hak tersebut di atas yang akan ditetapkan dengan undang-undang serta hak-hak yang sifatnya sementara sebagaimana disebutkan dalam Pasal 53.

Berdasarkan Penjelasan di atas bahwa UUPA telah mengatur berbagai jenis hak atas tanah, baik dimiliki oleh perorangan atau badan hukum, baik dimiliki secara sendiri-sendiri atau bersama-sama, sebagaimana dirumuskan dalam Pasal 16, yang didalam huruh h nya tercantum hak-hak lain yang akan diatur oleh UU, karenanya apabila akan mengatur hak baru maka harus diatur oleh UU.

Batasan kewenangan hak atas tanah pun sudah diatur dalam Pasal 4 (1) UUPA, yaitu bahwa hak atas tanah adalah hak atas permukaan bumi (dua demensi), selanjutnya dalam ayat (2) dicantumkan "sekedar" untuk keperluan yang berhubungan langsung dengan penggunaan tanah maka "pemegang hak dapat menggunakan tubuh bumi, atau ruang udara di atas permukaan bumi”. Pasal 4 tersebut dimaknai misalnya, pemegang hak dapat membangun rumah (di atas permukaan bumi), dan membangun pondasi rumah (di bawah permukaan bumi), yang penggunaan ruang tersebut berhubungan langsung dengan "penggunaan pembangunan rumahnya". Contoh lainnya adalah sumur air tanah dapat dibangun untuk menunjang kebutuhan atas penggunaan "permukaan buminya dalam bentuk rumah" demikian pula dengan kebutuhan basement baik sebagai area parkir atau gudang atau kios atau kantor sebagai penunjang kebutuhan atas permukaan bumi, itu sudah terpenuhi dengan aturan Pasal 4 tadi. Pemikiran atau makna Pasal 4 UUPA tadi adalah "pemegang hak hanya dapat menggunakan ruang di atas atau di bawah bumi "sekedar" berhubungan langsung dengan kebutuhan penggunaan permukaan tanahnya", karena sesungguhnya Pasal 4 ayat (1) adalah dua dimensi. Namun agar hak yang dua dimensi tersebut dapat dimanfaatkan oleh pemegang haknya, implementasi dari makna "sekedar" diterjemahkan dalam pengaturan tata ruang, dan pemberian ijin mendirikan bangunan (penggunaan ruang tiga dimensi), tetapi ambang batas tiga demimensinya tidak diatur, yaitu seberapa jauh batas ketinggian yang boleh dipergunakan pihak lain dan seberapa jauh batas kedalaman yang dapat dipergunakan pihak lain tidak diatur. Namun dalam konteks Pasal 4 tersebut di atas, pemegang hak dilarang membuat terowongan misalnya untuk jalan bawah tanah, yang melewati bawah pondasi rumahnya, di tanahnya sendiri sekalipun, apalagi bawah tanah orang lain, karena terowongan tersebut "tidak berhubungan dengan pondasi rumahnya dan tidak berhubungan kebutuhan langsung dengan bangunan rumahnya". Ini berarti bahwa pemanfaatan ruang bawah tanah seperti pembangunan Mall di Bawah Tanah, 
Jalur Kereta Api Bawah Tanah, dan bentukbentuk lainnya tidak termasuk dalam Pasal 4 UUPA ini. ${ }^{8}$

Terhadap bangunan yang dibangun di atas tiang-tiang penyangga, ruang di atas tanah diantara tiang-tiang itu tersebut bisa digunakan untuk tempat usaha atau keperluan lain. Hak-hak atas tanah yang tersedia juga bisa mengakomodasikan keberadaan bangunanbangunan yang sebagian besar strukturnya menggunakan ruang udara di atas tanah, dengan hanya memerlukan bagian-bagian permukaan bumi untuk menempatkan tiangtiang penyangganya. Seperti bangunan jalan layang, jembatan layang, jembatan penyeberangan dan jalan kereta api layang. Tanah di bawahnya bisa kepunyaan pemilik bangunan sendiri, yang dikuasai dengan Hak Guna Bangunan (HGB) atau Hak Pakai (HP). Pemegang HGB dan HP tersebut bukan hanya mempunyai kewenangan untuk menggunakan tanah yang bersangkutan, melainkan juga ruang udara yang ada di atasnya. Secara fisik bangunan yang dibangun pasti berhubungan dengan permukaan buminya melalui tiang-tiang penyangga yang ada. Tanah dibawahnya bisa juga dikuasai dengan Hak Pengelolaan oleh Pemerintah Daerah. Keberadaan bangunanbangunan di atasnya dilandasi HGB dan HP di atas HPL tersebut. Perlu diketahui bahwa keberadaan, bahwa keberadaan jalan umum, baik jalan negara, jalan propinsi, jalan kabupaten/kotamadya dan jalan desa sekalipun menurut hukum harus ada landasan hukumnya. Dengan pengertian demikian, untuk keberadaan dan penguasaan serta penggunaan bangunan

8 Ibid penghubung, jalan layang, jembatan layang, jembatan penyeberangan dan jalan kereta api layang yang dimaksudkan itu, tidak perlu diadakan lembaga hak baru, karena bisa dilandasi salah satu hak atas tanah yang ada. ${ }^{9}$

\section{UU Nomor 26 Tahun 2007 tentang Penataan Ruang}

Pengertian "ruang" menurut UU 26/2007 lebih luas dari pengertian ruang menurut UU 24/1992 sebagaimana dimuat dalam Pasal 6 ayat 3 bahwa penataan ruang wilayah nasional meliputi ruang wilayah yurisdiksi dan wilayah kedaulatan nasional yang mencakup ruang darat, ruang laut, dan ruang udara, termasuk ruang di dalam bumi sebagai satu kesatuan. Selanjutnya dalam ayat 4 dinyatakan penataan ruang wilayah provinsi dan Kabupaten/Kota meliputi ruang darat, ruang laut, dan ruang udara, termasuk ruang di dalam bumi sesuai dengan ketentuan peraturan perundangan yang berlaku. Kemudian Pasal 32 ayat (1) dan (2) menyebutkan bahwa:

1. Pemanfaatan ruang dilakukan melalui pelaksanaan program pemanfaatan ruang beserta pembiayaannya;

2. Pemanfaatan ruang sebagaimana dimaksud pada ayat (1) dapat dilaksanakan dengan pemanfaatan ruang, baik pemanfaatan ruang secara vertikal maupun pemanfaatan ruang di dalam bumi.

9 Boedi Harsono, Hukum Agraria Indonesia, Sejarah Pembentukan Undang-Undang Pokok Agraria, Isi danPelaksanaannya, Jilid 1 Hukum Tanah Nasional, Jakarta : Djambatan, 1997. 


\section{UU Nomor 28 tahun 2002 tentang Bangunan Gedung}

Pembahasan HGRBT juga terkait dengan Undang-Undang Nomor 28 Tahun 2002 tentang Bangunan Gedung serta peraturan pelaksanaannya, yakni Peraturan Pemerintah Nomor 36 Tahun 2005 tentang Peraturan Pelaksanaan Undang-Undang Nomor 28 Tahun 2002 tentang Bangunan Gedung telah menentukan adanya keberadaan gedung di ruang bawah tanah. Pasal 1 angka 1 UndangUndang Nomor 28 Tahun 2002 tentang Bangunan Gedung dijelaskan bahwa bangunan gedung adalah wujud fisik hasil kerja konstruksi yang menyatu dengan tempat kedudukannya sebagian atau seluruhnya berada di atas dan atau di bawah tanah. Hal ini berarti bahwa selain bangunan yang berada di atas permukaan bumi, ada pula bangunan yang berada di bawah permukaan bumi. Bangunan-bangunan tersebut terhadap tanah yang dilekatinya, apabila dianalogikan sama dengan bangunan yang berada di atas permukaan tanah, maka secara umum berlaku pula terhadapnya asasasas dan prinsip-prinsip hukum tanah nasional, tidak terkecuali asas pemisahan horizontal.

Kemudian pasal 7 ayat 4 disebutkan bahwa penggunaan ruang di atas dan/atau di bawah tanah dan/atau air untuk bangunan gedung harus memiliki izin penggunaan sesuai ketentuan yang berlaku. Kemudian Pasal ini dipertegas pada penjelasannya yang menyebutkan: Misalnya pembangunan bangunan gedung seperti mal, terminal, dan perkantoran yang dibangun di atas atau di bawah jalan atau sungai, termasuk yang berada di atas atau di bawah ruang publik. Izin penggunaan atau pemanfaatan ruang diberikan oleh instansi yang berwenang dan bertanggung jawab atas penyelenggaraan prasarana dan sarana umum atau fasilitas lainnya tempat bangunan gedung tersebut akan dibangun di atasnya atau di bawahnya.

Selanjutnya pada pasal 9 dinyatakan bahwa bangunan gedung yang dibangun di atas dan/ atau di bawah tanah, air, atau prasarana dan sarana umum sebagaimana dimaksud dalam Pasal 18 ayat (2) pengajuan permohonan izin mendirikan bangunan gedungnya dilakukan setelah mendapatkan persetujuan dari pihak yang berwenang." Yang dimaksud dengan prasarana dan sarana umum seperti jalur jalan dan/atau jalur hijau, daerah hantaran udara (transmisi) tegangan tinggi, dan/atau menara telekomunikasi, dan/atau menara air. Yang dimaksud dengan pihak yang berwenang adalah pihak/instansi yang bertanggung jawab dalam penyelenggaraan prasarana dan sarana. Hal ini berarti bahwa penghadiran bangunan gedung semacam ini akan melibatkan banyak pihak dengan kepentingannya.

Berdasarkan Pasal-pasal yang telah dijelaskan di atas berarti istilah Ruang Bawah Tanah telah dimasukkan dalam UU ini. Dengan kata lain, Undang-Undang Bangunan Gedung termasuk Peraturan pelaksanaannya dapat digunakan sebagai salah satu landasan hukum untuk pemanfaatan ruang bawah tanah.

\section{UU Nomor 34 tahun 2004 tentang Jalan}

Pasal yang mengatur penngunaan dan pemanfaatan ruang bawah tanah adalah 
pasal 1 butir 4, bahwa jalan adalah prasarana transportasi darat yang meliputi segala bagian jalan, termasuk bangunan pelengkap dan perlengkapannya yang diperuntukkan bagi lalu lintas, yang berada pada permukaan tanah, di atas permukaan tanah, di bawah permukaan tanah dan/atau air, serta di atas permukaan air, kecuali jalan kereta api, jalan lori, dan jalan kabel.

Undang-Undang ini dapat digunakan sebagai landasan hukum untuk pemanfaatan ruang bawah tanah dalam pengembangan infrastruktur terpadu.

\section{UU Nomor 23 tahun 2007 tentang Perkeretaapian}

Dalam UU ini Pasal yang mengatur berkaitan dengan pemanfaatan ruang bawah tanah adalah pasal 1 butir 4 bahwa Jalur kereta api adalah jalur yang terdiri atas rangkaian petak jalan rel yang meliputi ruang manfaat jalur kereta api, ruang milik jalur kereta api, dan ruang pengawasan jalur kereta api, termasuk bagian atas dan bawahnya yang diperuntukkan bagi lalu lintas kereta api. Selanjutnya butir 7 menyebutkan bahwa jalan rel adalah satu kesatuan konstruksi yang terbuat dari baja, beton atau konstruksi lain yang terletak di permukaan, di bawah dan di atas tanah atau bergantung beserta perangkatnya yang mengarahkan jalannya kereta api.

Undang-Undang ini dapat digunakan sebagai landasan hukum untuk pemanfaatan ruang bawah tanah dalam pengembangan infrastruktur terpadu.

\section{UU No 32 Tahun 2009 tentang Perlindungan dan Pengelolaan Lingkungan Hidup}

Dalam UU No 32 Tahun 2009 tidak secara spesifik mengatur pemanfaatan ruang dalam tanah, hanya menyebutkan adanya penerapan pajak lingkungan hidup bagi pengambilan air bawah tanah (penjelasan Pasal 43 UU No 32 Tahun 2009) dan tidak ada pengaturan secara spesifik mengenai perlindungan maupun pengelolaan Ruang Bawah Tanah.

\section{Undang-Undang Nomor 20 tahun 2011 tentang Rumah Susun}

Undang-Undang Rumah Susun termasuk salah satu UU yang dapat menjadi acuan pemanfaatan ruang bawah tanah. Dalam Pasal 47 disebutkan:

(1) Sebagai tanda bukti kepemilikan atas sarusun di atas tanah hak milik, hak guna bangunan, atau hak pakai di atas tanah negara, hak guna bangunan atau hak pakai di atas tanah hak pengelolaan diterbitkan SHM sarusun, (2) SHM sarusun sebagaimana dimaksud pada ayat (1) diterbitkan bagi setiap orang yang memenuhi syarat sebagai pemegang hak atas tanah, (3) SHM sarusun sebagaimana dimaksud pada ayat (1) merupakan satu kesatuan yang tidak terpisahkan yang terdiri atas : a. salinan buku tanah dan surat ukur atas hak tanah bersama sesuai dengan ketentuan peraturan perundang-undangan; b. gambar denah lantai pada tingkat rumah susun bersangkutan yang menunjukkan sarusun yang dimiliki; dan c. pertelaan mengenai besarnya bagian hak atas bagian bersama, benda bersama, dan tanah bersama bagi yang bersangkutan, (4) SHM sarusun sebagaimana dimaksud pada ayat (1) 
diterbitkan oleh kantor pertanahan kabupaten/ kota, (5) SHM sarusun dapat dijadikan jaminan utang dengan dibebani hak tanggungan sesuai dengan ketentuan peraturan perundanganundangan. Berdasarkan uraian tersebut jelas bahwa setiap pengaturan hak dan kewajiban bagi pemegang hak diatur dalam UU, oleh sebab itu hak guna ruang atas dan bawah tanah juga selayaknya diatur dalam UU, pemisahan azas horizontal akan memperkuat bahwa hak atas tanah sekedar hak atas permukaan bumi, sehingga pemilik tanah hanya dapat menggunakan ruang atas dan bawah tanah sekedar untuk keperluan yang berhubungan langsung dengan tanah sebagai permukaan bumi. oleh karena itu orang lain dapat melewati lorong di atas atau di bawahnya tanpa harus mendapatkan ijin pemilik tanah, karena lorong tersebut bukan dalam wilayah kepemilikannya.

\section{Undang-Undang Nomor 2 tahun 2012 Tentang Pengadaan Tanah Bagi Pembangunan Untuk Kepentingan Umum}

Dalam UU ini yang berkaitan dengan pemanfaatan ruang bawah dan atas tanah ada dalam Pasal 1 ayat 4 menyebutkan Objek Pengadaan Tanah adalah tanah, ruang atas tanah dan bawah tanah, bangunan, tanaman, benda yang berkaitan dengan tanah, atau lainnya yang dapat dinilai. Undang-Undang ini termasuk peraturan pelaksanaannya dapat digunakan sebagai landasan hukum untuk pemanfaatan ruang bawah tanah dalam pengembangan infrastruktur terpadu.

\section{Peraturan Menteri Pekerjaan Umum Nomor 02/Prt/M/2014 Tentang Pedoman Pemanfaatan Ruang Di Dalam Bumi}

Peraturan Menteri ini dibuat dengan konsideran berikut: a. bahwa dalam rangka mengatasi keterbatasan lahan di permukaan bumi, mewujudkan keterpaduan antar kegiatan, serta menjaga dan meningkatkan kualitas ruang dan kelestarian lingkungan diperlukan optimalisasi pemanfaatan ruang di dalam bumi; b. bahwa untuk meningkatkan efisiensi dalam pemanfaatan ruang di dalam bumi diperlukan pedoman sebagai acuan dalam pemanfaatan ruang di dalam bumi. Pasal 1 butir (1) menyebutkan bahwa ruang adalah wadah yang meliputi ruang darat, ruang laut, dan ruang udara, termasuk ruang di dalam bumi sebagai satu kesatuan wilayah, tempat manusia dan makhluk lain hidup, melakukan kegiatan, dan memelihara kelangsungan hidupnya. Ruang di Dalam Bumi yang selanjutnya disingkat RDB adalah ruang yang berada di bawah permukaan tanah yang digunakan untuk berbagai kegiatan manusia.

Pemanfaatan RDB adalah berbagai bentuk penggunaan ruang yang berada di bawah permukaan tanah untuk berbagai kegiatan manusia. Dalam Pasal 11 disebutkan jenis kegiatan beserta letaknya ditetapkan dengan memperhatikan tingkat kedalaman pemanfaatan RDB, tingkat kedalaman sebagaimana dimaksud terdiri atas : a. RDB dangkal; dan b. RDB dalam. RDB dangkal berada pada kedalaman 0 (nol) sampai dengan 30 (tiga puluh) meter di bawah permukaan tanah. sedangkan RDB dalam berada pada 
kedalaman lebih dari 30 (tiga puluh) meter di bawah permukaan tanah.

Selanjutnya Pasal 12 menyebutkan Pemanfaatan RDB dangkal sebagaimana dimaksud dalam Pasal 11 diprioritaskan untuk: a. kegiatan yang keberadaannya atau letaknya berdekatan atau berada tidak jauh atau menyatu dengan ruang atau kegiatan di permukaan; b. kegiatan yang membutuhkan akses dari dan ke RDB dangkal; c. kegiatan yang sumber dayanya terletak di RDB dangkal; dan $\mathrm{d}$. kegiatan yang berdasarkan hasil studi dan/atau alasan tertentu dapat atau harus ditempatkan pada RDB dangkal dan/atau tidak dapat ditempatkan pada RDB dalam.

Untuk Pemanfaatan RDB diprioritaskan terhadap : a. kegiatan yang menghubungkan antar pusat kegiatan, antar wilayah, dan/atau jaringan utama atau induk; b. kegiatan atau barang yang membutuhkan tingkat keamanan tinggi atau bersifat berbahaya; c. kegiatan yang sumber dayanya terletak di RDB dalam; dan d. kegiatan yang berdasarkan hasil studi dan/atau alasan tertentu dapat atau harus ditempatkan pada RDB dalam dan/atau tidak dapat ditempatkan pada RDB dangkal. Pemanfaatan RDB sebagaimana dimaksud baik untuk kepentingan publik maupun kepentingan privat harus mendapatkan rekomendasi teknis. Pemanfaatan RDB untuk kepentingan privat selain mendapatkan rekomendasi teknis juga harus mendapatkan izin. Rekomendasi teknis dan izin diberikan oleh instansi yang berwenang sesuai dengan ketentuan peraturan perundangundangan.

\section{Peraturan Gubernur Nomor 167 tahun 2012}

Pergub ini ini merupakan tindak lanjut dari Pasal 198 ayat (5) Peraturan Daerah Provinsi DKI Jakarta Nomor 1 Tahun 2012 tentang Rencana Tata Ruang Wilayah 2030.

\section{Pasal 1 Butir 15:}

Izin pemanfaatan ruang bawah tanah adalah izin yang diberikan untuk dapat memanfaatkan ruang bawah tanah dengan batas dan luas tertentu sebagai pengendalian pemanfaatan ruang bawah tanah.

\section{Pasal 3:}

Pemanfaatan ruang bawah tanah dilaksanakan sesuai dengan Rencana Tata Ruang Wilayah, RDTR dan Peraturan Zonasi serta Master Plan Pengembangan Kawasan dan Panduan Rancang Tata Kota pada lokasi kegiatan pemanfaatan ruang bawah tanah.

\section{Pasal 4:}

(1). Ruang bawah tanah terdiri atas ruang bawah tanah dangkal dan ruang bawah tanah dalam,

(2). Ruang bawah tanah dangkal merupakan ruang di bawah permukaan tanah sampai dengan ke dalaman 10 (sepuluh meter),

(3). Ruang bawah tanah dalam merupakan ruang di bawah permukaan tanah dari ke dalaman $10 \mathrm{~m}$ sampai dengan batas kemampuan pemanfaatan ruang bawah tanah. 


\section{Pasal 5:}

1) Kegiatan yang diperbolehkan pada ruang bawah tanah dangkal yaitu akses stasiun MRT, sistem jaringan prasarana jalan, sistem jaringan utilitas, kawasan perkantoran, fasilitas parkir, perdagangan dan jasa, pendukung kegiatan gedung di atasnya dan pondasi bangunan gedung di atasnya, 2) Kegiatan yang diperbolehkan pada ruang bawah tanah dalam yaitu sistem angkutan massal berbasis rel (MRT), sistem jaringan prasarana jalan, sistem utilitas dan pondasi bangunan gedung di atasnya.

\section{Pasal 7}

(1). Setiap badan usaha yang akan memanfaatkan ruang bawah tanah terlebih dahulu harus mendapatkan izin pemanfaatan ruang bawah tanah dari pemerintah daerah;

(2). Izin pemanfaatan ruang bawah tanah bertujuan untuk: a. Mengatur pemanfaatan ruang bawah tanah; b. Mengatur fungsi bangunan yang dapat dibangun; $c$. Mengatur ketinggian maksimum bangunan yang diizinkan; d. Mengatur jumlah lantai/ lapis bangunan di bawah tanah yang dizinkan dan mengendalikan lingkungan, geologi/kondisi bawah tanah dan air tanah;

(3). Izin pemanfaatan ruang bawah tanah dangkal secara umum mengikuti proses perizinan yang berlaku sebagaimana ruang di atas tanah, kecuali untuk zona tertentu yang ditetapkan secara khusus;

(4). Izin pemanfaatan ruang bawah tanah dalam hanyadapat diberikan secara khusus oleh
Gubernur berdasarkan rekomendasi dari Kepala SKPD.

Dari peraturan perundangan di atas belum ada yang secara spesifik mengatur mengenai penggunaan pemanfaatan Hak Guna Ruang Atas dan Bawah Tanah (HGRBT). Untuk mengakomodasikan keberadaannya berikut gagasan Prof. BudiHarsono secara lengkapnya: ${ }^{10}$

"bagian dalam tubuh bumi di bawah permukaan bumi dan bangunan di dalam bumi dalam ruang di atas tanah yang merupakan bagian dari bangunan induk yang berada di atas tanah masih dapat terakomodasi oleh hak-hak atas tanah yang ada, demikian bangunan dalam ruang di atas tanah yang bukan merupakan bagian dari bangunan induk, keadaan bangunan-bangunan seperti itu pun masih dapat terakomodasi dengan hak-hak yang ada. Keberadaannya pasti ada hubungan fisik dengan permukaan bumi di bawahnya, yang dikuasai dengan salah satu hak atas tanah yang ada.Berbeda dengan apa yang dikemukakan di atas, jika bangunan yang keberadaan dan penguasaannya belum terakomodasikan, yaitu bangunan-bangunan yang memerlukan ruang di dalam tubuh bumi, yang secara fisik tidak ada kaitannya dengan bangunan yang berada dipermukaan bumi di atasnya. Misalnya bangunan untuk kegiatan usaha pertokoan, restoran, setasiun dan jalan kereta api bawah tanah dan lain-lainnya.Untuk masuk dan keluar ruang yang bersangkutan memang diperlukan penggunaan sebagian permukaan bumi untuk lokasi "pintu". Tetapi karena bagian utama struktur bangunan berada di dalam tubuh bumi, isi kewenangan 
yang bersumber pada hak atas tanah sebagai yang ditetapkan dalam pasal 4 UUPA, yang utamanya mengenai penggunaan permukaan bumi, tidak mungkin ditafsirkan mencakup juga keberadaan dan penguasaan bangunanbangunan di bawah tanah yang dimaksudkan. Sehubungan dengan itu untuk keberadaan dan penguasaannya diperlukan lembaga hak baru, yang kiranya dapat diberi nama Hak Guna Ruang Bawah Tanah (HGRBT), melengkapi khasanah Hukum Tanah Nasional kita."

Pendapat ini didukung oleh Prof. Arie Sukanti Hutagalung yang berpendapat bahwa peraturan hak baru tersebut memerlukan suatu peraturan perundang-undangan dalam bentuk UU karena bangunan yang bersangkutan dapat berbentuk sebagai Rumah Susun, yang terdiri atas bagian-bagian yang dapat dimiliki secara individual dan terpisah satu dengan yang lainnya, dengan bagian-bagian lain menjadi milik bersama. Ada kewajiban-kewajiban dan pembatasan-pembatasan mengenai kewenangan para pemegang haknya dan para pemegang hakatas tanah di atasnya, yang pengaturannya memerlukan undang-undang. Maka selain memberikan kepastian hukum bagi pemegang haknya dan pihak-pihak lain yang kepentingannya bisa dipengaruhi oleh adanya bangunan tersebut.

Berbeda dengan pendapat di atas, Prof Maria S.W. Sumardjono berpendapat bahwa Pasal 4 UUPA 1960 sudah dapat mengakomodasi pemberian hak terhadap ruang bawah tanah melalui cara berpikir analogi dan interprestasi ekstensif. ${ }^{11}$ Sampai saat ini yang sudah diatur

11 Sumardjono, Kebijakan Pertanahan Antara Regulasi dan Implementasi, Jakarta, Kompas, 2007. adalah lembaga hak atas tanah yang meliputi permukaan bumi dengan ruang di bawahnya serta di atasnya sekedar diperlukan. Di luar strata itu, konsisten dengan hak menguasai Negara, maka ruang di bawah tanah dan ruang udara adalah hak Negara. Beliau berpendapat, secara analogi Negara dapat memberikan sesuatu hak di ruang bawah tanah dan udara. Dengan demikian Pasal 4 UU Nomor 5 tahun 1960 dapat diperluas cakupan berlakunya meliputi ruang di bawah tanah dan udara. Dengan perkataan lain, lembaga hak baru belum diperlukan. Menggunakan ruang bawah tanah sudah banyak contohnya di Indonesia. Bagianbagian bangunan yang disebut basement, ada yang digunakan sebagai parkir atau juga seperti tempat usaha seperti pertokoan, restoran, dan lain-lain.

\section{KESIMPULAN}

Kebutuhan akan ruang untuk pembangunan sangat tinggi sementara persediaan tanah terbatas, mengakibatkan penggunaan dan pemanfaatan ruang atas dan bawah tanah tidak dapat dihindari, baik untuk infrastruktur , perdagangan, jasa, perumahan dan sebagainya.

Ketentuan perundangan yang ada belum secara spesifik mengatur penggunaan dan pemanfaatan ruang atas tanah dan ruang bawah tanah, sehingga timbul berbagai interpretasi terhadap kasus-kasus penggunaan dan pemanfaatan ruang yang semakin memperkuat pendapat bahwa kemajuan pembangunan dan ekonomi tidak mampu dikejar oleh perangkat hukum kita, misalnya mengenai status hak ruang bawah tanah apakah sama dengan alas hak di 
atasnya. Ketentuan perundang-undangan yang ada belum mampu mengakomodir kemajuan pembangunan dan teknologi sehingga belum mampu menjawab permasalahan yang ada terkait penggunaan dan pemanfataan ruang atas dan bawah tanah.

Perlu pengaturan lebih lanjut setingkat UndangUndang (UU) tentang hak guna ruang atas tanah maupun hak guna ruang bawah tanah, seperti halnya jenis hak atas tanah yang diatur di dalam pasal 16 UUPA, mengatur subyek dan obyek hak, batasan penggunaan dan pemanfaatannya, jangka waktu haknya, peralihan haknya, jenis penjaminannya, serta sanksi terhadap pelanggarannya. Hal ini penting guna memberikan kepastian hukum dan perlindungan hukum atas pemegang hak guna ruang tersebut.

\section{SARAN}

Pengaturan ruang di atas dan di bawah tanah memerlukan upaya harmonisasi peraturan perundangan yang komprehensif, harmonisasi pengaturan tidak hanya terkait dengan pertanahan dan tata ruang, namun juga terkait dengan perundang-undangan di bidang lain seperti lingkungan, kehutanan, dan sektor terkait agar lebih efektif pelaksanaannya.

\section{DAFTAR ACUAN}

Harsono, Boedi. 1997. Hukum Agraria Indonesia, Sejarah Pembentukan Undang-Undang Pokok Agraria, Isi dan Pelaksanaannya, Jilid 1 Hukum Tanah Nasional. Djambatan. Jakarta.

Alrip, Ismail, Farida Patittingi, Faisal Abdullah. Pengaturan Pemanfaatan Ruang Bawah Tanah, Fakultas Hukum, Pascasarjana, Universitas Hasanuddin

Maharani, Sri. 2015. 'Hukum Ruang Bawah Tanah", Presentasi dan Paper dalam Focus Group Discussion Badan Pengembangan Infrastruktur Wilayah, Kementerian Pekerjaan Umum dan Perumahan Rakyat, 7-8 Oktober 2015, Jakarta.

Sumardjono. 2007. Kebijakan Pertanahan Antara Regulasi dan Implementasi. Kompas. Jakarta.

https://eleveners.wordpress.com/2010/01/19/ dir-pendaftaran-hak-tanah-dan-gunaruang/ www.bkm.go.id

http://blokmsquare.blogspot.com, 24 Mei 2014

http://the-kadi.blogspot.com

GTZ, 2003 